\title{
PENINGKATAN KEMAMPUAN MENULIS TEKS EKSPLANASI MENGGUNAKAN MEDIA AUDIO VISUAL PADA SISWA KELAS VIII SMP DHARMA PANCASILA MEDAN
}

\author{
Heppy Artika Sembiring ${ }^{1}$, Sadieli Telaumbanua ${ }^{2}$ \\ Universitas Prima Indonesia ${ }^{1}$, Universitas Prima Indonesia ${ }^{2}$ \\ pos-el: heppysembiring125@gmail.com¹, kadisgusti@gmail.com²
}

\begin{abstract}
ABSTRAK
Penelitian ini bertujuan untuk meningkatkan kemampuan menulis teks Eksplanasi dengan menggunakan media audio visual pada siswa kelas VIII SMP Dharma Pancasila Medan Tahun Pelajaran 2018/2019. Penelitian ini adalah penelitian tindakan kelas, yang terdiri dari dua siklus yaitu siklus I dan siklus II. Subjek penelitian siswa kelas VIII SMP Dharma Pancasila Medan. Pelaksanaan penelitian ini dilakukan berdasarkan permasalahan yang ada pada pembelajaran menulis teks Eksplanasi siswa masih tergolong rendah. Media audio visual yang digunakan dalam penelitian ini adalah kualitatif deskriptif dengan pendekatan tindakan kelas yang mendeskripsikan kemampuan menulis teks eksplanasi pada siswa secara klasikal dan kemampuan menulis teks eksplanasi melalui media audio visual. Berdasarkan hasil penelitian menunjukkan bahwa dengan menggunakan media audio visual dapat meningkatkan kemampuan menulis teks eksplanasi. Terbukti dengan adanya peningkatan hasil belajar siswa dari siklus I ke siklus II. Hasil tes siklus I di peroleh nilai rata-rata 65,38, dan tes siklus II meningkat dengan nilai rata-rata 81,53 dan telah mencapai $\mathrm{KKM} \leq 75$. Dilihat dari persentase ketuntasan klasikal siswa pada siklus I 34,61\% meningkat pada siklus II 92,30\%. Penelitian ini dapat disimpulkan bahwa dengan menggunakan media audio visual dapat meningkatkan kemampuan menulis teks eksplanasi pada siswa kelas VIII SMP Dharma Pancasila Medan.
\end{abstract}

\section{Kata kunci : Teks Eksplanasi, Media Audio Visual, Penelitian Tindakan Kelas}

\begin{abstract}
This study aims to improve the ability to write explanatory texts by using audio visual media in class VIII SMP Dharma Pancasila Medan Academic Year 2018/2019. This research is classroom action research, which consists of two cycles, namely cycle I and cycle II. Research subjects of class VIII SMP Dharma Pancasila Medan. The implementation of this research is based on the problems that exist in learning to write text. Explanation of students is still relatively low. The audio-visual media used in this study is descriptive qualitative with a class action approach that describes the ability to write explanatory texts to students classically and the ability to write explanatory texts through audio visual media. Based on the results of the study indicate that using audio visual media can improve the ability to write explanatory texts. Evidenced by the increase in student learning outcomes from cycle I to cycle II. The results of the first cycle test obtained an average value of 65.38, and the second cycle test increased with an average value of 81.53 and had reached KKM $\leq 75$. Viewed from the percentage of classical completeness of students in the first cycle $34.61 \%$ increased in the second cycle $92.30 \%$. This study can be concluded that by using audio visual media can improve the ability to write explanatory texts in class VIII SMP Dharma Pancasila Medan.
\end{abstract}

Keywords: Explanatory Text, Audio Visual Media, Classroom Action Research

\section{PENDAHULUAN}

Pada pelajaran Bahasa Indonesia terdapat empat aspek keterampilan yang selalu dilatih dan dikembangkan dalam pembelajaran. Keempat komponen itu ialah keterampilan menyimak, berbicara, membaca dan menulis. Salah satu keterampilan berbahasa yang dapat menjadi sarana komunikasi serta mengungkapkan ide kepada orang lain dan 
mampu meningkatkan kemampuan berbahasa terhadap siswa adalah keterampilan berbicara. Seseorang bisa menulis setelah melalui kegiatan keterampilan berbahasa yang lebih dulu dikuasai. Tarigan (2008:1) mengemukakan bahwa bahasa seseorang mencerminkan pemikirannya. Semakin terampil seseorang berbahasa semakin cerah dan jelas pula jalan pemikirannya. Keterampilan hanya dapat diperoleh dan dikuasai dengan praktik dan berlatih. Maka, siswa harus sering berlatih menulis agar dapat mengasah kemampuan menulisnya.

Kemampuan menulis akan sangat bermanfaat bagi siswa maupun orang lain. Melalui kegiatan menulis seseorang dapat menuangkan pikiran, perasaan, dan gagasan. Menulis bagi beberapa orang bukanlah mudah seperti yang dialami para siswa ketika mereka mendapat tugas menulis. Masih banyak siswa yang mengalami kesulitan dalam hal menulis para siswa merasa sulit menentukan gagasan atau topik yang akan ditulis.

Saat ini beberapa sekolah sudah menerapkan kurikulum baru yang diberi nama kurikulum 2013. Mata pelajaran bahasa Indonesia dalam kurikulum 2013 berbasis teks. Materi yang dipelajari dalam mata pelajaran Bahasa Indonesia VIII SMP adalah teks hasil observasi, tanggapan deskripsi, eksposisi, eksplanasi dan cerita pendek. Teks eksplanasi merupakan teks baru yang dipelajari dalam mata pelajaran Bahasa Indonesia sehingga perlu diadakan penelitian untuk mengetahui kemampuan siswa dalam menulis teks eksplanasi.

Teks eksplanasi adalah teks yang menjelaskan tentang proses terjadinya atau terbentuknya suatu fenomena alam atau sosial. Dalam menulis teks eksplanasi, masih banyak kesulitan yang di hadapi siswa. Ada siswa yang sulit menentukan gagasan dan ada juga siswa sudah bisa menentukan gagasan tetapi sulit untuk mengembangkan gagasan menjadi satu tulisan yang utuh.

$$
\text { Menurut Kosasih }
$$
menjelaskan pengertian teks eksplanasi, yakni teks yang menjelaskan suatu peristiwa, baik itu berupa peristiwa alam, peristiwa sosial, dan budaya ataupun peristiwa pribadi. Pristiwa alam, misalnya, proses banjir dan gunung berapi, Pristiwa sosial/budaya misalnya proses upacara adat, proses penerimaan siswa baru dan proses menjalankan Ibadah Keagamaan. Teks eksplanasi merupakan teks eksplanasi berisi tentang proses-proses yang berhubungan dengan jawaban penulis yang menjawab pertanyaan mengapa (why) dan bagaimana (how) terhadap suatu fenomena yang ada. Mulyadi (dalam Wahyuningtias 2015:22), hal yang harus diingat dalam isi teks eksplanasi adalah menjelaskan sesuatu hal yang berangkat dari fakta untuk kemudian menghasilkan kesimpulan umum agar pembaca menyetujui pendapat dan sikapnya. Menurut Yulianti (2015:11) ada beberapa langkah yang dilakukan dalam menulis teks eksplansi, antara lain. 1) Menentukan topik yang akan disajikan. Topik atau tema dapat ditemukan dengan berbagai cara misalnya melalui sebuah pengamatan objek secara langsung. 2) Menentukan tujuan teks eksplanasi. Penulis harus memiliki tujuan yang nantinya memberi penjelasan dan pemahaman kepada pembaca. 3) Membuat kerangka tulisan.

Berdasarkan uraian di atas, dapat disimpulkan bahwa teks eksplanasi merupakan salah satu jenis teks yang di dalamnya berisi tentang proses terjadinya suatu peristiwa baik peristiwa alam maupun peristiwa sosialSesuai dengan standar kompetensi dalam silabus kelas VIII, peserta didik diharapkan mampu menulis teks eksplanasi. Akan tetapi kenyataannya berbeda 
pada saat observasi dilakukan di SMP Dharma Pancasila Medan. Kenyataan tersebut diperoleh dari wawancara dengn guru bahasa Indonesia di sekolah tersebut. Hasil tersebut diperoleh bahwa nilai siswa dengan menulis teks eksplanasi belum mencapai KKM. Masih banyak peserta didik yang belum mampu menulis teks eksplanasi. Nilai KKM yang ditentukan sekolah adalah 75 namun hanya $50 \%$ yang dapat memenuhi target yang telah ditetapkan. Peneliti memilih judul ini karena teks ini merupakan teks baru yang harus dipelajari siswa SMP dalam kurikulum 2013. Ada beberapa hal yang menyebabkan rendahnya kemampuan peserta didik dalam kemampuan menulis teks eksplanasi. Diantaranya adalah kurangnya kemauan belajar siswa dalam menulis teks eksplanasi. Banyak peserta didik yang kurang tertarik dengan kegiatan menulis. Rendahnya minat siswa dalam menulis teks eksplanasi karna kurangnya kosa kata yang dimiliki siswa. Banyak peserta didik yang masi menggunakan bahasa yang terdapat dalam buku.

Selain minat peserta didik yang rendah, penyebab rendahnya keterampilan menulis teks eksplanasi pada peserta didik karna peserta didik merasa bosan terhadap media yang digunakan guru. Guru mengajar dengan cara konvensional sehingga peserta didik kurang aktif dalam proses belajar mengajar. Guru harus menggunakan media yang tepat agar hasil proses belajar mengajar dapat tercapai.

Media pembelajaran merupakan suatu alat pembelajaran yang digunakan oleh guru dalam proses belajar mengajar yang bertujuan untuk mencapai tujuan pembelajaran yang diharapkan. Oleh karna itu kita harus memilih media pembelajaran, pendidik juga harus memperhatikan karakteristik peserta didik.

Menurut Gerlach dan Ely (Dalam azhar Arsyad 2013:3) menyatakan bahwa media adalah manusia, materi, atau kejadian yang membangun kondisi yang membuat siswa mampu memperoleh pengetahuan keterampilan. Atau sikap, Azhar Arsyad (2013:3) menyatakan bahwa media pembelajaran adalah "sebagai alat-alat grafis, photografis, atau elektronis untuk menangkap memproses dan menyusun kembali informasi visual atau verbal. Azhar Arsyad (2013:32) menyatakan bahwa media audio visual adalah produksi dan penggunaan materi yang penyerapannya melalui pandangan dan pendengaran sera tidak seluruhnya tergantung kepada pemahaman kata atau simbol-simbol yang serupa. Media audio visual menyampaikan materi dengan menggunakan mesin-mesin mekanis dan elektronik untuk menyajikan pesan-pesan audio dan visual. Munandi (2016:56) mengatakan "Media audio visual adalah media yang melibatkan indra pendengaran dan penglihatan sekaligus dalam suatu proses".

Peneliti ini menggunakan media pembelajaran audio visual dikarenakan dapat menciptakan kondisi dan suasana belajar peserta didik lebih kondusif dikarenakan pada proses pembelajarannya lebih banyak menyimak.

Perencanaan dan kreativitas ada dua hal yang berhubungan dan juga tampak berlawanan dalam pengembangan media. Pertama menghendaki prosedur perencanaan yang terstruktur yang membutuhkan pengorganisasian, memperhatikan urutan yang logis dan integritas terhadap keutuhan pesan. Kedua menghendaki alur ide dan ekspresi yang bebas dan tak terstruktur yang dihasilkan oleh berpikir kreatif dan mengacu pada masalah yang timbul selama pengembangan media berlangsung.

Kita juga dapat memulai dengan perencanaan dengan ide yang muncul dalam benak kita. Suatu ide mungkin mengindikasikan minat yang kita miliki. 
Motivasi juga salah satunya, memberi informasi atau mengajarkan sesuatu. Kita juga perlu menentukan apakah media yang kita buat bertujuan memotivasi memberi informasi atau mengajarkan sesuatu. Media audio visual merupakan wahana penyampaian informasi atau pesan pembelajaran peserta didik melalui media audio visual diharapkan agar guru dapat melihat langsung perkembangan anak. Manfaat menggunakan audio visual menurut Munandi (2016:135) sebagai berikut. a) Mempermudah dalam penyampaian dan menerima pembelajaran atau informasi serta dapat menghindarkan salah pengertian. b) Mendorong keinginan untuk mengetahui lebih banyak, hal ini disebabkan karena sifat audio visual yang menarik. c) Tidak membosankan, maksudnya ialah karena sifatnya yang variatif. Siswa dalam pembelajaran tidak merasa bosan karna sifatnya yang beragam film, tiga dimensi atau empat dimensi. Hal ini dapat menciptakan sesuatu yang variatif tidak membosankan para siswa.

Berdasarkan permasalahan tersebut, pembelajaran memerlukan media yang menarik untuk mendulang berlangsungnya proses pembelajaran. Dalam proses pembelajaran guru sangat berperan penting terhadap keberhasilan pemahaman peserta didik dalam pembelajaran menulis teks eksplanasi. Guru harus bisa memotivasi peserta didik dalam pembelajaran serta mampu memilih media yang tepat. Berdasarkan pemaparan tersebut peneliti akan mengkaji "Peningkatan Kemampuan Menulis Teks Eksplanasi Menggunakan Media Audio Visual Pada Siswa Kelas VIII SMP Dharma Pancasila Medan Tahun Pelajaran 2018/2019”.

Peneliti ini menggunakan media pembelajaran audio visual dikarenakan dapat menciptakan kondisi dan suasana belajar peserta didik lebih kondusif dikarenakan pada proses pembelajarannya lebih banyak menyimak.

\section{METODE PENELITIAN}

Sugiyono (2016: 3) mengatakan bahwa "Pendekatan penelitian merupakan cara ilmiah untuk mendapatkan data dengan tujuan dan kegunaan tertentu. Penelitian ini dilakukan dengan menggunakan pendekatan Penelitian Tindakan Kelas (PTK)". Arikunto (2013:134) mengatakan penelitian tindakan kelas merupakan suatu penelitian yang akar permasalahannya ada di kelas dan dirasakan langsung oleh guru yang bersangkutan sehingga sulit dibenarkan jika ada anggapan bahwa permasalahan dalam PTK diperoleh dari persepsi dari seorang peneliti. PTK merupakan penelitian yang menggunakan siklus atau tindakan yang berkelanjutan, maka putaran atau siklusnya minimal 2 kali setiap putaran melalui empat tahap, yaitu perencanaan, tindakan, pengamatan, refleksi.

Penelitian tindakan kelas yaitu penekanan pada kegiatan (tindakan) melalui uji cob ide ke dalam praktik atau situasi nyata yang diharapkan kegiatan tersebut mampu memperbaiki dan meningkatkan kualitas proses belajar mengajar di kelas.

Berdasarkan hal tersebut pendekatan yang digunakan dalam penelitian ini adalah pendekatan kualitatif dengan metode PTK yang merupakan jenis penelitian berdasarkan atas data deskriptif dari setiap individu berupa sikap dan perilaku bisa diamati selama proses pembelajaran berlangsung. Penelitian ini dilaksanakan di SMP Dharma Pancasila Medan pada kelas VIII Tahun Pelajaran 2018/2019, Jln. Dr. Mansyur No. 71 A 
Medan. Penelitian ini dilaksanakan pada semester genap tahun pelajaran 2018/2019. Subjek penelitian ini adalah siswa kelas VIII SMP Dharma Pancasila Medan Tahun Pembelajaran 2018/2019 yang berjumlah 30 siswa, dengan 13 siswa laki-laki dan 17 siswa perempuan. Objek dalam penelitian ini adalah penerapan media audio visual untuk meningkatkan keterampilan menulis teks eksplanasi di kelas VIII SMP Dharma Pancasila Medan Tahun Pelajaran 2018/2019.

Teknik pengumpulan data dalam penelitian ini adalah wawancara, observasi, dokumentasi, dan tes kemampuan menulis sebuah teks eksplanasi (Sugiyono (2016:137). Lembar observasi digunakan untuk mengamati kemampuan berbicara siswa. Pada tahap observasi ini peneliti menggunakan tanda check list pada lembar observasi.

Teknik analisis data yang digunakan dalam penelitian tindakan kelas ini menggunakan teknik analisis deskriptif kualitatif. Analisis data ini dilakukan dengan kolaboratif antara penelitian dan guru Bahasa Indonesia berdasarkan refleksi dari data yang terkumpul. Teknik analisis data kualitatif dalam penelitian ini digunakan untuk menganalisis data-data yang berupa proses kegiatan pembelajaran. Penghitungan skor observasi kegiatan penelitian siklus I dan Siklus ke II dapat diketahui dengan menggunakan rumus:

$$
\mathrm{X}=\frac{\sum_{i}^{m}=1 x i}{m}
$$

Dengan sederhana rumus di atas adalah sebagai berikut :

$$
X=\frac{X_{1}+X_{2}}{2}
$$

Keterangan:

1. $X=$ rata-rata hasil pengamatan

2. $\mathrm{m}=$ banyak pengamatan
3. $\mathrm{i}=$ jumlah data

Keberhasilan penelitian tindakan kelas (PTK) SMP Dharma Pancasila Medan adalah sebagai berikut apabila nilai kriteria ketuntasan minimal (KKM) kemampuan menulis teks eksplanasi $>75$ dan nilai kriteria ketuntasan klasikal (KKK) 75\% dari jumlah siswa". Maka dapat disimpulkan pada mata pelajaran Bahasa Indonesia SMP Dharma Pancasila Medan adalah apabila nilai KKM kemampuan menulis teks eksplansi $>75$ dan nilai KKK $75 \%$ dari jumlah siswa, maka penelitian tindakan kelas mata pelajaran Bahasa Indonesia dengan topik kemampuan menulis teks eksplanasi berhasil.

Rumus untuk menghitung tingkat ketuntasan belajar adalah

$$
\mathrm{p}=\frac{\sum \text { siswa yang tuntas belajar }}{\sum \text { siswa }} \times 100 \%
$$

Tabel 1. Kriteria-Kriteria Rata-Rata Observasi atau Pengamatan

\begin{tabular}{|c|c|}
\hline \multicolumn{1}{|l|}{ Hasil } & Arti \\
\hline $0,1-1,1$ & Artinya buruk \\
\hline $1,2-2,1$ & Artinya kurang baik \\
\hline $2,2-3,1$ & Artinya baik \\
\hline $3,2-4,0$ & Artinya sangat baik \\
\hline
\end{tabular}

(Sudjana, 2015)

\section{HASIL DAN PEMBAHASAN}

Proses pembelajaran pada penelitian ini yang sudah dilaksanakan peneliti yang sudah menerapkan media audio visual untuk memperbaiki keterampilan menulis teks eksplanasi pada siswa kelas X SMA Parulian 1 Medan telah mendapatkan hasil penelitian dengan menyatakan bahwa keterampilan siswa menulis teks biografi yang telah diamati dapat meningkat. Hasil penelitian ini terlihat dari penilaian tes 
yang diberikan kepada siswa untuk dikerjakan di setiap tahap tahap kegiatan pembelajaran yang telah dilakukan penelitian yaitu siklus I, dan siklus II.

Pelaksanaan pembelajaran menulis teks biografi pada siklus I diberikan tes awal untuk mengetahui kemampuan awal pemahaman siswa terhadap materi pembelajaran menulis teks eksplanasi dengan menerapkan media audio visual. Adapun hasilnya, 9 siswa $(34,61 \%)$ yang lulus mendapatkan standar nilai KKM 75. Sedangkan siswa yang belum lulus mendapatkan nilai 75 ada 17 siswa $(65,38 \%)$.

Dalam hal tersebut, peneliti pun melakukan perlakuan untuk memperbaiki situasi pembelajaran menulis teks eksplanasi yang terjadi di kelas VIII-A dengan melakukan tindakan pembelajaran yaitu memperbaiki penerapan media audio visual untuk menulis teks eksplanasi yang dilaksanakan pada siklus II. Dari kegiatan pembelajaran tersebut sudah dilaksanakan dan hasil pelaksanaannya telah ditemukan jawabannya bahwa penerapan media audio visual dapat meningkatkan kemampuan menulis teks eksplanasi pada siswa kelas VIII-A SMP Dharma Pancasila Medan. Adapun bukti data peningkatan nilai hasil pembelajaran menulis teks eksplanasi siswa siklus I dan siklus II dari tes yang telah diberikan pada akhir proses pembelajaran di tiap siklusnya adapun hasilnya 24 siswa dengan persentase $92,3 \%$ yang tuntas dan ada 2 siswa dengan persentase $7,6 \%$ tidak tuntas mencapai standar KKM.

Berdasarkan hasil tersebut penelitian peningkatan kemampuan menulis teks eksplanasi menggunakan media audio visual sudah menunjukkan hasil yang lebih baik. Dengan demikian peneliti tidak perlu melakukan siklus selanjutnya dan hanya dilakukan sampai siklus II karena telah terbukti bahwa kegiatan pembelajaran menyimak dalam menulis teks eksplanasi sudah berhasil mencapai standar KKM.

Untuk memberikan gambaran yang jelas atas pencapaian hasil penelitian yang telah meningkat pada siklus I dan siklus II dari hasil tes dalam pembelajaran menulis teks biografi dapat dilihat melalui diagram 1 sebagai berikut.

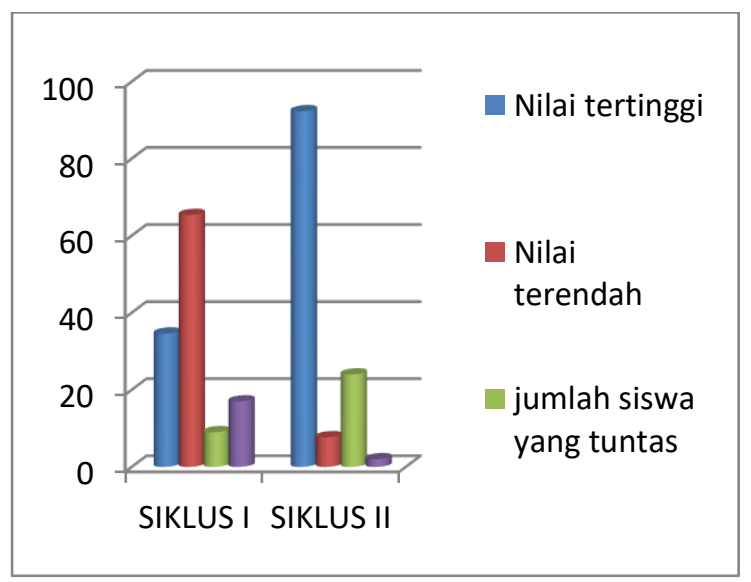

Berdasarkan penelitian yang telah dilakukan bahwa proses pembelajaran yang menerapkan media audio visual dapat meningkat kemampuan menulis teks eksplanasi siswa kelas VIII-A. Oleh karena itu, media audio visual pada mata pelajaran Bahasa Indonesia dapat berperan penting untuk meningkatkan keterampilan menulis teks eksplanasi siswa apalagi media audio visual adalah produksi dan penggunaan materi yang penyerapannya melalui pandangan dan pendengaran serta tidak seluruhnya tergantung kepada pemahaman kata atau simbol-simbol yang serupa. Artinya dalam pembelajaran menulis teks eksplanasi dengan menggunakan media audio visual di kelas VIII-A tersebut dapat meningkatkan kemampuan media audio visual siswa menyampaikan materi dengan menggunakan mesin-mesin mekanis dan 
elektronik untuk menyajikan pesan-pesan audio dan visual.

Media audio visual menjadikan siswa lebih aktif, mandiri, dan antusias saat proses pembelajaran berlangsung. Siswa dituntut untuk berkonsentrasi penuh saat menulis teks eksplanasi. Media pembelajaran ini lebih menekankan peran siswa dalam pembelajaran, peneliti hanya berperan sebagai fasilitator dalam pembelajaran seperti mengondisikan keadaan pembelajaran yang sedang berlangsung di kelas. Siswa hanya menulis kembali teks eksplanasi yang di tayangkan menurut strukturnya, hingga hasil akhirnya mampu memahami isi menulis teks eksplanasi dari peserta didik yang dapat dilihat hasilnya dari penilaian pengerjaan tes keterampilan menulis dalam peningkatan kemampuan menulis teks eksplanasi peserta didik di setiap akhir siklus pembelajaran.

Media pembelajaran pada proses pembelajaran menyimak dalam peningkatan kemampuan menulis teks eksplanasi telah dilaksanakan melalui beberapa tahap tindakan pembelajaran sebanyak dua siklus. Masing-masing siklus dilakukan 2 x 40 menit dalam dua kali pertemuan yaitu 160 menit. Berdasarkan hasil observasi dan analisis dari siklus I dan II, pembelajaran keterampilan peningkatan kemampuan menulis teks eksplanasi dengan menerapkan media audio visual mengalami peningkatan terhadap hasil pembelajaran peningkatan kemampuan menulis teks eksplanasi peserta didik yang dilihat dari data hasil tes di akhir pembelajaran.

Dari keberhasilan dengan sudah meningkatnya peningkatan kemampuan menulis teks eksplanasi siswa kelas VIIIA, namun berdasarkan hasil pengamatan peneliti dan guru dari lembaran observasi kegiatan guru dan kegiatan siswa pada siklus I dan siklus II terdapat beberapa aspek permasalahan yang telah diuraikan di tahap observasi sebelumnya. Lalu direncanakanlah proses perlakuan perbaikan dalam suatu tindakan di setiap siklusnya. Bukan hanya itu, pada kegiatan pembelajaran siswa saat pembelajaran dengan media audio visual di siklus I hanya 65,3 nilai rata-rata keseluruhan peserta didik yang dapat dinyatakan memiliki tingkat penguasaan keterampilan menulis "tinggi".

Hal ini karena masih banyak siswa yang tidak mengikuti instruksi peneliti untuk membaca dan mempelajari ulang materi pembelajaran yang telah disampaikan, tidak semua siswa dapat memiliki konsentrasi yang tinggi, dan siswa belum terbiasa dalam menggunakan media audio visual pada proses pembelajaran dengan baik dan benar sehingga masih ada siswa yang tidak memedulikan saat media audio visual di terapkan dalam kelas.

Pada proses pembelajaran di siklus II yang masih menerapkan media audio visual sudah mengalami peningkatan. Hasil pembelajarannya mendapat nilai rata-rata keseluruhan siswa adalah 92,3 yang dapat dinyatakan memiliki tingkat penguasaan keterampilan menulis berkategori "tinggi". Hal ini karena sudah banyak siswa yang mau membaca dan mengikuti instruksi dari peneliti dalam proses pembelajaran peningkatan kemampuan menulis teks eksplanasi sehingga mendorong siswa untuk berkonsentrasi untuk menulis. Mereka sudah terbiasa dan sangat antusias untuk melakukan pembelajaran dengan menggunakan media audio visual penggali pemahaman siswa dari hal-hal yang telah 
dibacanya selama proses pembelajaran berlangsung sehingga terbukti terjadi peningkatan keterampilan menulis siswa.

Namun dari semuanya itu, guru dan peneliti menyatakan bahwa proses pembelajaran dalam menerapkan media audio visual untuk meningkatkan kemampuan peningkatan kemampuan menulis teks eksplanasi siswa kelas VIIIA SMP Dharma Pancasila Medan sudah berjalan dengan baik dan lancar. Terlihat dari hasil penilaian di siklus I dan siklus II meningkat sesuai dengan Kriteria Ketuntasan Minimal $(\mathrm{KKM}) \geq 75$ dan nilai persentase Ketuntasan Klasikal siswa dengan nilai $\geq 75 \%$. Dengan demikian, dapat disimpulkan bahwa berdasarkan rumusan masalah di Bab I dan hipotesis tindakan pada Bab II telah dinyatakan dan dipaparkan pada hasil penelitian di Bab IV ini, dalam penerapan media audio visual dapat meningkatkan peningkatan kemampuan menulis teks eksplanasi pada siswa kelas VIII-A SMP Dharma Pancasila Medan. Dalam hal tersebut dapat membantu guru bidang studi Bahasa Indonesia untuk lebih aktif lagi dalam mengelola kondisi kelas.

Terdapat beberapa aspek penilaian terhadap pembelajaran peningkatan kemampuan menulis teks eksplanasi pada siswa, yakni ketepatan isi tanggapan. Dari aspek penilaian tersebut meningkat pada siklus I, siklus II.

\section{KESIMPULAN}

Peningkatan hasil pembelajaran menulis teks eksplanasi dengan media audio visual telah meningkat. Terbukti dari hasil penelitian nilai siklus I 34,61\% dan terjadi peningkatan siklus II 92,2\%.Oleh karena itu, strategi pembelajaran media audio visual pada bidang studi Bahasa Indonesia dengan sub pokok pembahasan materi pembelajaran menulis sangat berperan penting untuk meningkatkan kemampuan menulis teks eksplanasi siswa dan mampu memberikan motivasi serta kesenangan siswa dalam proses pembelajaran kemampuan menulis teks eksplanasi yang terkadang membuat siswa jenuh atau bosan sehingga siswa dapat lebih aktif dan lebih bersemangat dalam proses pembelajaran kemampuan menulis teks biografi di kelas VIII-A SMP Dharma Pancasila Medan.

\section{DAFTAR PUSTAKA}

Arikunto. 2013. Penelitian Tindak Kelas. Jakarta: Bumi Aksara.

Arsyat, Azhar. 2013. Media Pembelajaran. Jakarta: Rajawali.

Kosasih. 2016. Jenis-jenis Teks. Bandung: Margahayu Permai.

Munandi, Yudhi. 2016. Media Pembelajaran. Cipayung: Gaung Persada (GP) Press.

Sugiyono. 2016. Teknik Pengumpulan Data. Bandung. Alfabeta. Sumiati

Sudjana. 2005. Metoda Statistika. Bandung: Tarsito.

Tarigan. 2008. Menulis sebagai Ketermpilan Berbahasa. Bandung: Angkasa Group. 